\title{
Historical roots of entrepreneurship in different regional contexts-the case of Poland
}

\author{
Michael Fritsch (D) Korneliusz Pylak (D) \\ Michael Wyrwich
}

Accepted: 30 June 2021 / Published online: 24 July 2021

(C) The Author(s) 2021

\begin{abstract}
Entrepreneurship is often found to be highly persistent over time. Although the historical roots of persisting effects of entrepreneurship are partially uncovered, their mechanisms remained largely unclear. To understand the historical roots of contemporaneous regional entrepreneurship, we exploit different types of historical self-employment in regions of Poland, a country that experienced different types of disruptive developments. In contrast to previous studies on other countries, we do not find a persistent effect of the general level of historical private sector self-employment. There is, however, a pronounced positive relationship between high regional levels of knowledge-intensive entrepreneurship in the 1920s and current start-up activity in general, even in areas where large parts of the local population were displaced after World War II. We find that the magnitude of this effect is independent of the mobility and an exchange of the local population. Our main
\end{abstract}

M. Fritsch · M. Wyrwich

Friedrich Schiller University Jena, Jena, Germany

K. Pylak ( $\bowtie)$

Lublin University of Technology, Lublin, Poland

e-mail: korneliusz.pylak@pollub.pl

M. Wyrwich

University of Groningen, Groningen, The Netherlands conclusion is that the historical regional knowledge stock, as reflected by knowledge-intensive entrepreneurship, can be an important and stable historical root of modern entrepreneurship despite disruptive historical shocks and population discontinuities.

Plain English Summary Historical knowledgeintensive entrepreneurship is a major root of current entrepreneurship despite disruptive historical shocks and population replacement. We draw on Poland's turbulent history since the 1920 s to investigate the regional roots of today's entrepreneurship. Compared to previous studies, we do not find a persistent effect of the general level of historical private sector entrepreneurship. Only historically high levels of high-quality entrepreneurship are positively related to current start-up activity, even in areas where much of the local population has been displaced. This suggests that the historical regional knowledge stock can be an important historical root of modern entrepreneurship despite disruptive historical shocks and population discontinuities. Therefore, entrepreneurship policy should seek to stimulate the regional knowledge stock and the creation of high-quality start-ups in a region. Examples of successful current and historical local entrepreneurs can provide important roadmaps on how to become successful entrepreneurs and potentially create a place-based collective memory. 
Keywords Entrepreneurship · Historical roots · Knowledge $\cdot$ Start-ups $\cdot$ Poland

JEL Classification $\quad \mathrm{L} 26 \cdot \mathrm{M} 13 \cdot \mathrm{O} 1 \cdot \mathrm{O} 18 \cdot \mathrm{R} 11$

\section{Introduction}

Numerous studies that explore historical roots of economic activity suggest that the development of regions follows long-term trajectories (e.g., Bleakley \& Lin, 2012; Dalgaard et al., 2018; Davis \& Weinstein, 2002). Regarding entrepreneurship previous research found a rather remarkable trend of long-term persistence $^{1}$ despite disruptive changes of social, political, and institutional framework conditions (Fotopoulos \& Storey, 2017; Fritsch \& Wyrwich, 2014; Glaeser et al., 2015). The nature of such historical roots and the ways by which they become effective are, however, largely unexplored. Particularly, we still do not know much about the mechanisms and channels behind such long-term relationships in different regional-historical contexts.

This paper contributes to the literature by analyzing the link between different types of historical selfemployment and current levels of start-up activity across the regions of Poland. The country is a fascinating quasi-natural laboratory that is well suited for such an investigation for several reasons. First, the regions of contemporaneous Poland were characterized by huge pre-World War II (WWII) differences with respect to economic structure, political context, and the level of economic development. While some regions were highly industrialized and host of many successful manufacturing firms, other parts were dominated by small-scale agriculture and hardly had any entrepreneurial and industrial tradition. Second, over the last century, all parts of Poland experienced several disruptive changes including WWII, four decades of socialism followed by a shock-like transition towards a market economy. Since the intensity of

\footnotetext{
$\overline{1}$ Persistence here does not mean that the levels of entrepreneurship are more or less constant, but we use the term in the sense of a positive statistical relationship, i.e., historical levels of entrepreneurship contribute to explaining the levels in later time periods. Hence, regions with relatively high (or low) levels of entrepreneurship in earlier periods will also experience relatively high (or low) levels in later periods.
}

these disruptions considerably varied between different parts of the country, there is rich opportunity to investigate the effect of different types of entrepreneurship and historical disruptions on the long-term entrepreneurial development, particularly the strength of historical roots.

Our study contributes to the knowledge about historical roots of regional entrepreneurship in several ways. First, we identify a long-term positive effect of the historical regional level of self-employment in knowledge-intensive manufacturing industries on current new business formation regardless the historical regional contexts. In contrast to previous evidence from studies on the persistence in entrepreneurship, no such effect can be found for other types and the general level of entrepreneurship. The positive effect of self-employment in knowledge-intensive industries is particularly remarkable since it represented only a rather tiny share of the overall level of self-employment in the 1920s. An explanation for this result could be that self-employment in knowledge-intensive industries represents entrepreneurship of particularly high quality in terms of abilities and economic impact that has a positive long-run effect on the overall level of start-up activity. Our result directs the attention to the role of a region's historical knowledge stock that may be an important root of contemporary entrepreneurship despite historical shocks.

Second, we find that the positive effect of high historical levels of knowledge-intensive entrepreneurship on current new business formation is independent of changes in the composition of the local population. Even a more or less complete exchange of the local population does not seem to play a significant role in the strength of this relationship. This suggests that the effect of historical knowledge-intensive entrepreneurship does not necessarily require the intergenerational transmission of entrepreneurial attitudes and abilities in the local population. This finding may be explained by the presence of a place-based collective memory about historically successful (knowledgeintensive) entrepreneurship that does not require a persistent population. Last but not least, we provide the first study of historical roots of regional entrepreneurship for the case of Poland, a unique historical playground for testing historical origins of presentday entrepreneurship in distinct contexts.

The remainder of the paper is organized as follows. The next section (Section 2) lays out the conceptual 
framework and derives the key hypotheses of our analysis. We then provide a brief overview of recent Polish history that is helpful for understanding our empirical strategy (Section 3). Data sources and variables are described in Section 4. Section 5 presents the results of the empirical analysis, and the final section summarizes the empirical evidence, discusses its limitations, and draws conclusions for policy and further research.

\section{Empirical evidence and potential explanations}

\subsection{Persistence of entrepreneurship in different regional contexts}

Positive relationships between regional levels of entrepreneurship over longer periods of time that was found in several previous studies indicate the relevance of historical roots. Such persistence of regional entrepreneurship could be explained in different ways. One of such explanations is stability of ("sticky") regional conditions (see Andersson \& Koster, 2011; Fotopoulos, 2014; Fritsch \& Kublina, 2019). Persistence of regional entrepreneurship is, however, also found in contexts with several disruptive changes of the social, political, and institutional environment, as was the case in East Germany (Fritsch \& Wyrwich, 2014). An explanation for the persistence of entrepreneurship in such disruptive environments could be the presence of intangible factors in society, specifically entrepreneurship-facilitating informal institutions such as societal norms, values, and codes of conduct that are transferred across generations (Chlosta et al., 2012; Dohmen et al., 2012; Laspita et al., 2012; Lindquist et al., 2015). Research has shown that such informal institutions maintain a degree of independence from changes of the social, economic, and political context, particularly changes of formal rules, and tend to evolve only slowly over long periods of time (North, 1994; Williamson, 2000).

A rather remarkable example of persistent entrepreneurship was found for the Russian region of Kaliningrad that was marked by disruptive shocks and an exchange of the population leaving no room for an explanation based on an intergenerational transmission of entrepreneurship-facilitating informal institutions by definition (Fritsch et al., 2019b). ${ }^{2}$ Based on the example of Kaliningrad, Fritsch et al. (2019b) introduce another intangible factor for explaining persistence of entrepreneurship that they call "place-based collective memory of entrepreneurship." It represents an awareness of the regional entrepreneurial history of a region, particularly of successful historical entrepreneurship (for details of the concept of collective memory as such, see Olick et al., 2011). It can be understood as the remembrance of time-distant role models that may be prevalent in both stable and disruptively changing contexts. In the case of a stable context, however, this mechanism cannot be clearly disentangled from the effect of essentially unchanged regional conditions. ${ }^{3}$

\subsection{Types of historical entrepreneurship and their persisting effects}

Previous studies provide indication that not all types of historical entrepreneurship are related to current start-up activity. For example, Fritsch et al. (2019a) found for the case of Germany no significant relationship between the regional shares of home workers as well as self-employment in agriculture on new business formation in later periods. An explanation for this result could be that these two types

\footnotetext{
2 The area of Kaliningrad was part of Germany until the end of WWII in 1945. In the aftermath of the war, the area saw disruptive changes in the economic, social, and political framework conditions. One of these disruptions was the displacement of the original German population soon after the war with the new population coming from diverse parts of Russia. The region then endured four decades of socialism during which self-employment was almost illegal. This was followed by another disruptive transition toward a market economy that was accompanied by massive economic dislocation and decline.

${ }^{3}$ Places typically have their own meaning, a social construct that reflects collective histories, memories, and identities (David et al., 2017; Gieryn, 2000; Zukin, 2011). In this respect, place is also the interplay of location, meaning, and material form (Gieryn, 2000). The establishment of new firms can be affected by a place-based collective memory, since place-bound features of local communities, such as: market structures, types of public policies, relational systems and networks, history, tradition, and even features of physical geography, can exert a significant influence on organizational behavior (Marquis \& Battilana, 2009). A place-based collective memory of earlier entrepreneurship in the new population may be based on remaining buildings, documents, and narratives.
} 
of self-employment represent only low levels of entrepreneurial behaviors such as innovation and risk taking. Furthermore, Fritsch et al. (2019a) identify a robust and statistically significant relationship between historical levels of self-employment in science-based industries, current new business formation as well as current levels of innovative activity. These results suggest an important role of a historical tradition of knowledge-intensive entrepreneurship and the historical regional knowledge base for current levels of entrepreneurship. ${ }^{4}$

There are several reasons to assume that selfemployment in knowledge-intensive industries represents entrepreneurship of a relatively high-quality that may generate particularly pronounced role model effects and induce further self-employment. First, setting up and running a knowledge-intensive firm requires specific qualifications. Since knowledgeintensive start-ups are relatively likely to introduce risky innovations, setting up and successfully running such a firm requires certain entrepreneurial attitudes and abilities. Second, although failure rates of historical start-ups in knowledge-intensive industries were maybe in about the same range or even higher than in other sectors of the economy, it is plausible to assume that the surviving firms in this field were more likely to generate a significant positive impact on regional development than other types of self-employment, e.g., by being economically and technologically successful and creating considerable numbers of promising entrepreneurial opportunities. ${ }^{5}$ For these reasons one can expect that positive role model effects of selfemployment in knowledge-intensive industries are generally more pronounced than is the case for selfemployment in other parts of the economy. Based on these arguments regions with relatively high levels of self-employment in knowledge-intensive industries should have inherited a greater number of highquality entrepreneurs that can serve as attractive role

\footnotetext{
4 The study of the Kaliningrad region (Fritsch et al., 2019b) also finds indication for a particularly pronounced effect of historical entrepreneurship in industries where firms in the past used relatively advanced production technology.

5 Although there is no solid empirical evidence available that would allow us to assess the performance of firms in different industries in the time before WWII, most of those firms that are remembered today were innovative and knowledge intensive.
}

models and facilitate the prevalence of a place-based collective memory that stimulates higher levels of new business formation many years later.

\section{Persisting effects of historical entrepreneurship in different regional-historical contexts: the case of Poland}

We know from the literature that historical entrepreneurship (Section 2.1) can have a significant impact on current start-up activity. We also know that there can be long-term effects of historical entrepreneurship even in situations where the original population was more or less completely replaced (Fritsch et al., 2019b). However, we do not know whether the magnitude of these effects depends on certain historicalregional context factors. For example, we do not know whether persistent effects are weaker when there are more or certain kinds of disruptive shocks as compared to other contexts, for example, when there is an exchange in the original population in some places but not in the others. The diversity of Polish regions in terms of both their levels of economic development and their turbulent histories over the past centuries provides a well-suited framework for investigating the role of historical roots of entrepreneurship. In the following, we first give an overview on recent history of Poland (Section 3.1) and then explain how we use the diversity of regional-historical context for our empirical analysis (Section 3.2).

\subsection{A brief overview of recent Polish history}

During the Polish partitions between 1772 and 1918, the country was split up and assigned to AustriaHungary, Prussia (which became part of the German Empire in 1871), and Russia. At that time, economic development of most parts of the country lagged behind many Western European countries (Koryś, 2018, 15-18). Poland regained sovereignty over parts of its former territories at the end of the First World War (WWI) in 1918. At that time, Poland also claimed territories in the east (the Kresy) that fell to the Soviet Union after WWII, and are currently part of the Ukraine, Belarus, and Lithuania. Figure A.1 in the Appendix shows the regions of Poland today with their historical affiliations. 
Until the end of WWII, some northern regions and the western areas of contemporaneous Poland were part of Germany. In the last months of the war, the German population of this area fled from the approaching Russian Army or was expelled after the war. The incoming population came from other parts of Poland, particularly from the Kresy. By the year 1950 , only $19.6 \%$ of the population in the pre-1945 German areas was indigenous, $49.1 \%$ was displaced from other regions of post-war Poland, and 29.5\% were repatriates and returnees, the vast majority of those $(86.1 \%)$ from former Polish territories (for further details, see Kosiński, 1963, 47, 61; Curp, 2006; Becker et al., 2020). Beginning in 1945, the country experienced more than 40 years of state-mandated socialism, then made a rapid transition to a marketbased economy in the 1990s, followed by accession to the European Union in 2004.

For our empirical analysis, the economic history of the contemporaneous Polish regions is the most interesting because of the tremendous differences in the levels of population expulsion, entrepreneurship, industrialization, and economic development among them. The regions that were already Polish before WWII were characterized by general economic backwardness, coinciding with a permanent lack of capital and low levels of private investment (Sawicki \& Sawicka-Brockie, 1982), factors that severely hampered any attempts at industrialization. The overall workforce's level of education was considerably lower than in the German regions. The economy was dominated by agriculture with a few industrial centers, such as the steel and textile industries around Lodz and Bialystok, and the oil industry around Boryslaw and in the Carpathians region, which today belongs to Ukraine (Koryś, 2018). At that time the newly established Polish state showed a pronounced tendency to take over private firms, particularly those who had economic problems after the Great Depression of the late 1920s (Macieja, 2001).

Although the previously German part of contemporary Poland was much more economically developed than the rest of the country, it also exhibited significant differences throughout its territories. In the southeastern region of Silesia, self-employment flourished before WWII, fueled by rapid industrialization, high levels of innovation, and a relatively well-developed education system (Geiss, 2013; Kouli, 2014). In contrast, the northern and northeastern regions were considerably less economically and technologically advanced (Kokot, 1959; Pierenkemper, 1979; Tipton, 1974). Their economies were dominated by largescale farms often owned by nobles, and there were high levels of outmigration.

After WWII, the largest part of the Polish economy was nationalized and became subject to a planned economic system under socialist regime. Selfemployment, while not almost illegal as in the Soviet Union (Gerber, 2004, 277), was highly regulated and fraught with challenges due to arbitrary laws and state despotism (Aslund, 1985). In 1990, the reintroduction of a market economy system induced a tremendous blossoming of self-employment, leading to 1.3 million self-employed people by 1995 , which accounted for $9 \%$ of the workforce (Rutkowski, 1998, 48). The number of self-employed people stabilized at 1.33 million in 2002 (7.95\% of total workforce) and reached 1.52 million in 2011 (8.88\% of total workforce), a level slightly lower than that of post-socialist East Germany (Fritsch et al., 2014).

\subsection{Setting the scene of potential roots of entrepreneurship in Poland}

The considerable diversity of historical political regimes as well as of economic structures and levels of development make Poland an ideal spatial framework for analyzing historical roots of entrepreneurship. Moreover, comparing those parts of the country where population was replaced with other parts where it remained relatively stable allows for investigating the role of different types of historical shocks as well as identifying the relevance of different channels for a transmission of entrepreneurship over time. Persistence in areas that were already part of Poland before 1945 could be driven by an intergenerational transmission of historical entrepreneurship and entrepreneurship-facilitating values as well as by a placebased collective memory of (high-quality) entrepreneurship. However, if we find the persistence of this phenomenon in the former German part, where the largest part of the original population was replaced because of WWII, this can hardly be driven by intergenerational transmission. This persistence can therefore rather be attributed to a place-based collective memory of entrepreneurship that was particularly activated during the period of transformation to a market economy in the 1990s. 
Based on our assumptions concerning the role of the regional knowledge base and the quality of entrepreneurship in the prevalence of a place-based collective memory of successful entrepreneurship (see Section 2), we expect that historical levels of high-quality self-employment should contribute to explaining current levels of entrepreneurship. Therefore, we distinguish between knowledge-intensive and non-knowledge intensive historical entrepreneurship in the empirical assessment. Note, that knowledgeintensive entrepreneurship in Poland made only a tiny share of self-employment in the 1920s. In the German part, only $2.5 \%$ of all self-employed (excluding agriculture) and in the Polish part only $1 \%$ (excluding agriculture) were in knowledge-intensive industries. Hence, if our conjecture about the role of historic self-employment in knowledge-intensive industries is correct, we may find higher levels of current entrepreneurship in the formerly German part of Western Poland (Silesia) that was far more industrialized and economically developed before WWII than the rest of the country (see Section 3.1). In that case, the historical economic structure of that area would have been particularly conducive to the prevalence of a place-based collective memory of successful entrepreneurship. At the same time, given the extremely low shares of knowledge-intensive entrepreneurship historically any effect on the general level of start-up activity is unlikely an effect of persistence of industry structures.

Conversely, however, the replacement of the original German population at the end of WWII has largely impeded the intergenerational transmission of entrepreneurship and entrepreneurship-facilitating values. Hence, we have no firm hypothesis on whether the effect of high-quality historical entrepreneurship on current start-up activity will be weaker or stronger in the former German regions of Western Poland when compared to the rest of the country. Comparing the effect size of the historical legacy of high-quality entrepreneurship across the types of regions will, however, provide insights as to whether persistence of population magnifies the effect of a history of high-quality entrepreneurship on current start-up activity.

\section{Data sources and variables}

\subsection{Main variables of interest: historical self-employment and current start-up activity}

\subsubsection{Dependent variable}

We determine the current level of entrepreneurial activity based on the start-up rates in different types of industries. Specifically, we divide the number of new businesses in the non-agricultural private sector by the number of economically active persons, employed and unemployed (Audretsch \& Fritsch, 1994). Since registration is mandatory in Poland for both the self-employed and commercial legal companies, the data should reliably reflect the level of new business formation. ${ }^{6}$ To avoid possible bias related to short-term and stochastic effects, we use the average regional start-up rates over a longer period. The longest time series of available data on start-ups in Poland covers the period from 2003 to 2019. Information on the number of economically active persons is available only for the census years 2002 and 2011. We use the information on the workforce for the year 2011 , because it falls in the middle of the observation period. The data is provided by Statistics Poland (GUS).

\subsubsection{Independent variables}

We rely on two different data sources for constructing our historical variables. The historical data for the former German regions is based on the full population and occupation censuses (Volks- und Berufszählungen) conducted on June 16, 1925 (Statistik des Deutschen Reichs, 1927). The census divides the number of working people into self-employed and paid employees, based on an industry stratification. The historical data for Poland is based on the first dwellings, population and occupation census, conducted on September 30, 1921 (GUS, 1927). This census also provides information on the number of self-employed persons versus paid employees. Both

\footnotetext{
6 The register also contains some firms that never take up any significant commercial activity. There is, however, no indication that the share of these firms varies across regions. New branch plants are generally not included in the number of startups unless they have a separate VAT number.
} 
the German and the Polish censuses cover the entire populations of their respective countries. ${ }^{7}$ Because the censuses were conducted in very similar ways, the data are highly comparable. Both censuses provide information at the county level. Since the historical borders of the counties differ considerably from the current ones, we transformed the data into current LAU 1 (Local Administrative Units) regions using Geographical Information Systems software (ArcGIS and QGIS).

Because information on the historical start-up rates is not available, we follow prior studies (e.g. Fritsch \& Wyrwich, 2014; Fotopoulos \& Storey, 2017) in using the self-employment rate to gauge entrepreneurial tradition. The self-employment rate reflects the historical conditions for starting and running an own business, thus both measures, i.e., start-up rates and self-employment, are significantly correlated. The share of those self-employed (sole proprietors and employers) in knowledge-intensive industries over the number of economically active persons in 1921 (for Poland) and 1925 (for Germany) is regarded as a proxy for high-quality high-impact entrepreneurship.

We include those manufacturing industries in the 1920s as knowledge-intensive where knowledge played a crucial role in the production process. We use the definition of Fritsch and Wyrwich (2018) to classify the production of machinery and electrotechnical equipment, basic precious metals, watches, clocks and precision instruments as well as the chemical industry as knowledge intensive. There were certainly additional industries in which technical knowledge played an important role, however, because the censuses give such broad definitions to the industries, the level of knowledge-intensity could not be adequately determined in many such cases. Therefore, we were forced to be conservative in our choices of knowledge-intensive industries and selected only those that could confidently be assumed to utilize

\footnotetext{
7 There are a few regions where historical self-employment rates are not available: (1) The Free City of Danzig that was a semi-autonomous city-state under the protection of the League of Nations, and thus, neither belonged to Germany nor Poland at that time; (2) some Upper Silesian counties incorporated into the territory of Poland after three Polish uprisings in the years 1919-1921 were not included in the Polish Census in 1921, nor the German Census in 1925.
}

high levels of technical knowledge, as well as be comparable between the two census groups.

We also calculate the historical non-knowledgeintensive self-employment rate, measured as the number of self-employed in all other industries (except agriculture) over the economically active population, to explore how this self-employment rate relates to current start-up activity. We expect a much less pronounced relationship between this measure and current start-up activity.

\subsection{Method}

We apply OLS regressions to analyze the relationship between historical knowledge-intensive entrepreneurship and current start-up rates. To be more precise, we regress the current average start-up rate (startuprate $r$ ) on the historical self-employment in knowledge-intensive industries $\left(\right.$ know $\left._{r}\right)$ in regions $r$. Hence, our specification is:

startuprate $_{r}=\frac{\frac{1}{17} \sum_{i=2003}^{2019} \operatorname{startups}_{i, r}}{\text { workforce }_{2011, r}}=\beta_{1}+\beta_{2}$ know $_{r}+\gamma_{r}+\varepsilon_{r}$

In this equation, $\gamma_{r}$ represents a vector of control variables for region $r$ that we introduce and explain in the following section; $\varepsilon_{r}$ represents the error term.

\subsection{Control variables}

We consider several pre-WWII regional structural characteristics in the time period for which we have information on self-employment as well as migration patterns during WWII and in early post-war years. We also include dummy variables that indicate whether a region was part of Germany before 1945, or not, and dummy variables to control for regions belonging to Prussia, Austria, or Russia before 1918, the year when the Polish partition ended. We also consider the distance to the current German border to control for unobserved heterogeneity related to the new spatial organization of post-WWII Poland and Germany.

We use mainly historical controls instead of contemporaneous ones as current structural characteristics and migration patterns are likely an outcome of historical conditions, including historical self-employment. Hence, use of contemporaneous controls would imply spurious correlation with our 
main variables of interest and could severely bias our estimates.

Among the pre-war controls, we include workforce density in the 1920s. This covers several regional characteristics that could influence the level of entrepreneurship, such as urbanization economies where the practice and impacts of entrepreneurship could be witnessed by larger groups of people (see for example, Andersson \& Koster, 2011; Fotopoulos, 2014). It is also plausible to expect that the level of entrepreneurship is shaped by the available knowledge and level of access to higher education (Acs et al., 2009). Thus, our model also includes the distance to the nearest university in the 1920s. The rationale behind this variable is that knowledge spillovers are limited in range.

Since Glaeser et al. (2015) and Stuetzer et al. (2016) found a significant relationship between the level of entrepreneurship and the geographic distance to coal mines (low levels of entrepreneurship in and around coal mining regions), we include the distance of a county to the nearest operating coalmine in the 1920s. To account for industry structure, we introduce the percentage of people working in manufacturing industries in the total number of the working population in the 1920s.

Apart from pre-WWII structural characteristics, we control for migration patterns as reflected by regional shifts of population between 1939 and 1950 (Davies $\&$ Moorhouse, 2011). First, we consider the proportion of the indigenous population after WWII, i.e., the share of the total regional population in 1950 that already lived in the same NUTS 2 region in $1939 .{ }^{8}$ To capture interregional migration resulting from WWII, we introduce the share of repatriates from former Polish territories that became part of Russia after WWII (the Kresy) in the total population in the year 1950, as well as the share of population that migrated from other regions of today's Poland. Moreover, we consider the share of repatriates and immigrants returning from other countries in the total population in 1950.

\footnotetext{
${ }^{8}$ NUTS stands for Nomenclature of Territorial Units for Statistics, the definition of regions at different levels of aggregation used by Eurostat, the statistical agency of the European Union. See https://ec.europa.eu/eurostat/web/nuts/background
}

Table A.1 in the Appendix provides an overview of the main variables of interest and the control variables with their definitions and sources. Table A.2 provides separate descriptive statistics for areas that were part of Germany before 1945 and the remaining areas of Poland. Table A.3 shows correlations between the variables.

\section{Results of the empirical analysis}

\subsection{Descriptive insights}

Figure 1a and b present self-employment in knowledge-intensive (Fig. 1a) and in all other industries excluding agriculture (Fig. 1b) over the economically active population in the 1920 s. Figure 1a shows that in the 1920s entrepreneurial activity in knowledgeintensive industries was rather low, reaching a maximum of $0.5 \%$ of the total workforce in urban areas. ${ }^{9}$ These industries were particularly concentrated in the southwestern part of Poland, predominantly in the region that was German until WWII. Also, the level of self-employment in pre-1945 German areas was at a rather high level, while in the rest of Poland it is mainly concentrated in larger cities such as Warsaw, Lodz, Lublin, and Cracow as well as in Upper Silesia. Industrial development around these places was at a relatively high level, albeit spotty. Table A.2 in the Appendix shows that the average level of selfemployment in knowledge-intensive industries was nearly three times higher in the pre-1945 German areas (0.172) than in the rest of Poland (0.063), indicating an overall higher level of industrialization. This higher degree of industrialization in the pre1945 German area is also evidenced by plotting the share of employment in total manufacturing and the share of employment in knowledge-intensive manufacturing in the total workforce (see Fig. B.1 in the Appendix).

Self-employment in other than knowledge-intensive industries (except agriculture) in the 1920s

\footnotetext{
${ }_{9}$ However, in nominal values, the number of self-employed in knowledge-intensive industries was quite considerable, reaching 14,709 in Poland as a whole, with an average of 45 entrepreneurs in each county. For example, in Warsaw, the number of such entrepreneurs was 2007, in Wroclaw it was 1135, in Lodz 504, and in Cracow 307.
} 
(a)

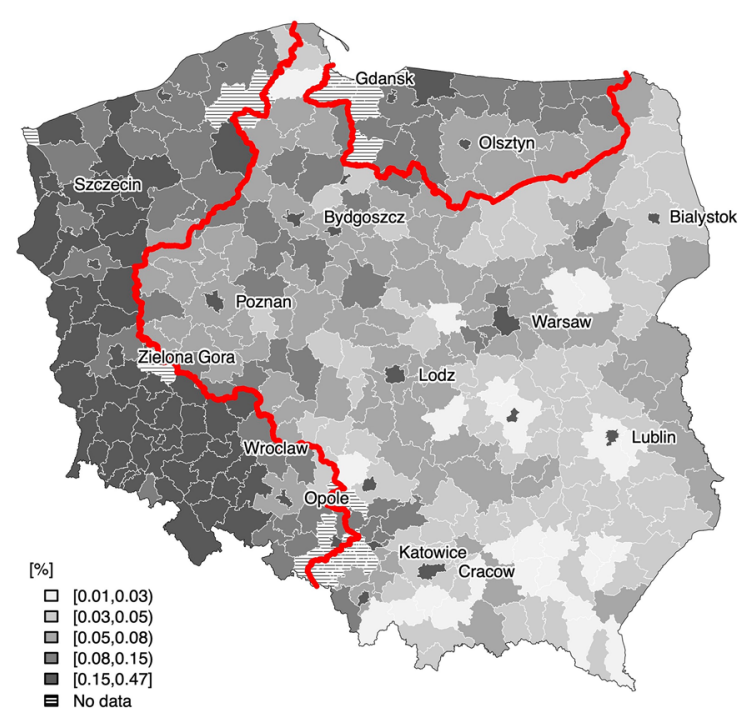

Fig. 1 Self-employment in knowledge-intensive manufacturing industries (a) and in other non-agricultural private sector industries (b) per total workforce in the 1920s. Note: The bold line represents the border between the pre-1945-German

reveals a rather different distribution. Although the highest shares of self-employed in these industries in the economically active population can be also observed in the southwestern part of Poland, numerous counties in the Eastern and Central part of Poland (with an average of 6.1, see Table A.2 in the Appendix) exhibit equally high shares of self-employment in these industries. In the pre-1945 German part of contemporaneous Poland, the average level of selfemployment in other industries slightly was higher (6.7\% of the economically active population) and more evenly distributed (from 3.2 to $12.2 \%$ ).

Figure 2 shows the regional distribution of startup rates today. The highest rates can be found in the Western and Northern part of Poland, especially around Szczecin, Gdansk, Zielona Gora, and Wroclaw, areas that were German until 1945. The highest levels of start-ups in the former Polish part are found closer to the former German border-around the metropolitan areas of Poznan and Bydgoszczbut many are also seen around Warsaw, Lodz, Cracow, and the mountainous areas at the southern border of the country. Although visual inspection of the regional distribution of current start-up rates suggests (b)

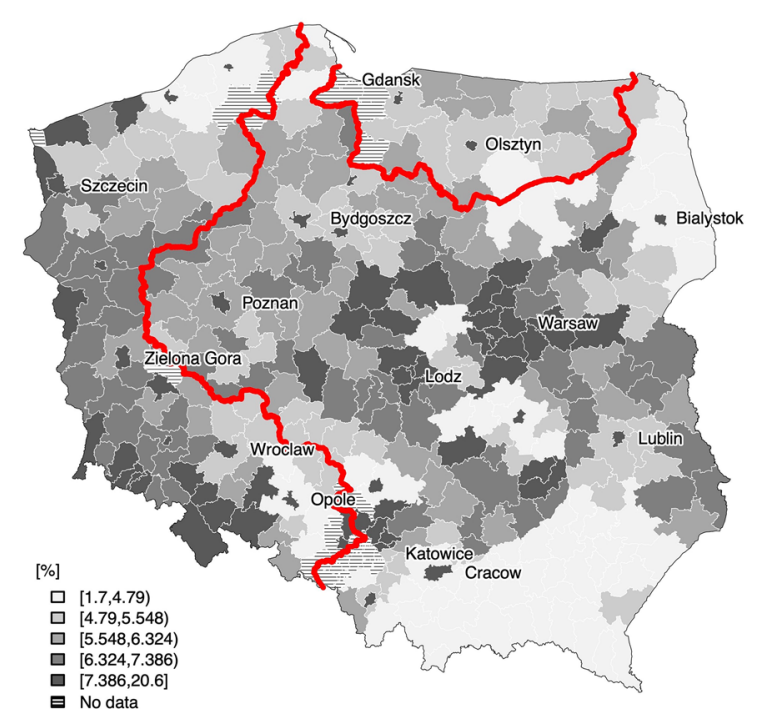

and Polish territory. For a bigger picture, the self-employment in non-knowledge-intensive manufacturing is presented in Fig. B.2 in the Appendix

pronounced differences from the historical selfemployment rates in knowledge-intensive industries (Fig. 1a), there is significant positive correlation. This correlation between current start-ups and historical self-employment in knowledge-intensive industries is quite high (0.557) compared to a correlation between current start-ups and the historical self-employment in the other industries except agriculture (0.411) and non-knowledge-intensive manufacturing industries (0.318) (see also Fig. B.3(b) and (c) in Appendix B).

\subsection{Main results}

The results of the analysis designed to test our conjecture that historical levels of knowledge-intensive and high-quality entrepreneurship have persisting effect on current start-up rates are presented in Table 1 . In model I, we only include the historical rate of selfemployment in knowledge-intensive industries. In model II, we add pre-war controls, including the dummy indicating regions being part of Germany until 1945. Model III also contains controls for migration resulting from WWII. In models IV and V, we interact pre-WWII controls as well as migration 
Fig. 2 Start-up rates in 2003-2019 per total workforce. Note: The bold line represents the border between the pre-1945-German and Polish territory

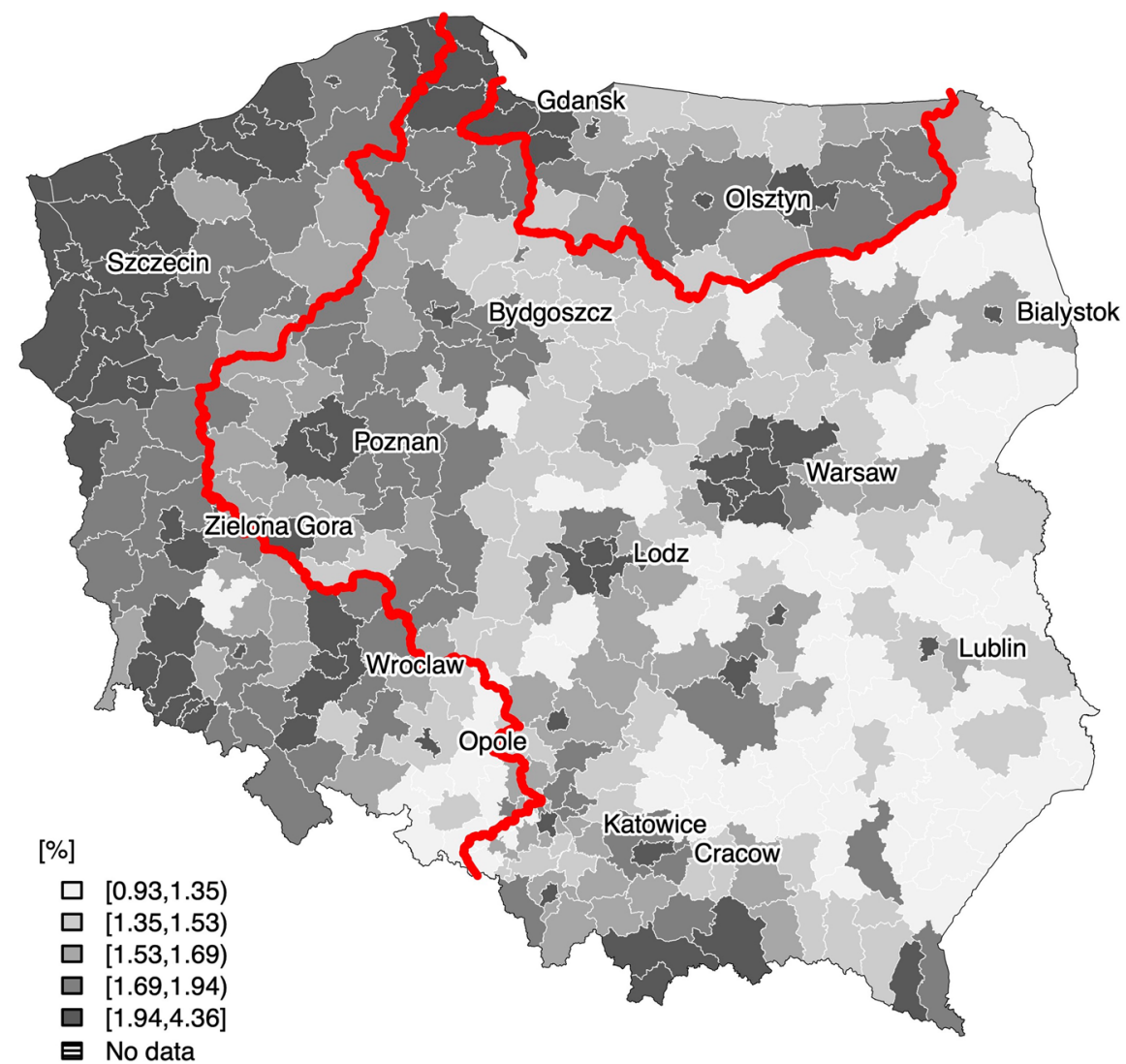

Table 1 Differences in start-up rates across Polish counties 2003-2019: the role of historical entrepreneurship in knowledge-intensive industries

\begin{tabular}{|c|c|c|c|c|c|c|}
\hline & I & II & III & IV & $\mathrm{V}$ & VI \\
\hline Historical self-employment in knowledge-intensive industries & $\begin{array}{l}0.169 * * * \\
(0.013)\end{array}$ & $\begin{array}{l}0.114 * * * \\
(0.028)\end{array}$ & $\begin{array}{l}0.095 * * * \\
(0.027)\end{array}$ & $\begin{array}{l}0.114 * * * \\
(0.028)\end{array}$ & $\begin{array}{l}0.109 * * * \\
(0.027)\end{array}$ & $\begin{array}{l}0.126^{* * *} \\
(0.031)\end{array}$ \\
\hline Pre-WWII German heritage $($ yes $=1$ ) & No & Yes & Yes & Yes & Yes & Yes \\
\hline Pre-WWII controls & No & Yes & Yes & Yes & Yes & Yes \\
\hline Migration resulting from WWII & No & No & Yes & Yes & Yes & Yes \\
\hline Pre-WWII German heritage $($ yes $=1) \times$ Pre-WWII controls & No & No & No & Yes & Yes & Yes \\
\hline $\begin{array}{l}\text { Pre-WWII German heritage }(\text { yes }=1) \times \text { migration resulting } \\
\text { from WWII }\end{array}$ & No & No & No & No & Yes & Yes \\
\hline $\begin{array}{l}\text { Pre-WWII German heritage }(y e s=1) \times \text { historical self-employ- } \\
\text { ment in knowledge-intensive industries }\end{array}$ & No & No & No & No & No & $\begin{array}{l}-0.083 \\
(0.047)\end{array}$ \\
\hline Adjusted $\mathrm{R}^{2}$ & 0.344 & 0.428 & 0.485 & 0.494 & 0.540 & 0.541 \\
\hline
\end{tabular}

Notes: The dependent variable is the average start-up rate $(\log )$ in 2003-2019. Number of observations is $\mathrm{N}=328$. Pre-war controls are workforce density, the share employed in manufacturing, the distance to universities and the distance to coal mines. Migration controls following WWII include the share of indigenous people, immigrants from Russia, and immigrants from other countries. In all models, we include a dummy variable that controls whether a region was part of Austria before 1918 and a dummy variable that controls whether a region was part of Russia before 1918 (reference group: regions that belonged to Prussia before 1918). A model with all coefficient estimates for these controls is presented in Table B.1 in Appendix B. All independent variables except dummies are in logs. Constant is not shown for brevity. Robust standard errors are shown in parentheses. ***Statistically significant at the $1 \%$ level, **statistically significant at the $5 \%$ level, *statistically significant at the $10 \%$ level 
Table 2 Differences in start-up rates across Polish counties 2003-2019: The role of historical entrepreneurship in non-knowledgeintensive industries (excluding self-employment in agriculture)

\begin{tabular}{|c|c|c|c|c|c|c|}
\hline & I & II & III & IV & $\mathrm{V}$ & VI \\
\hline Historical self-employment in other than knowledge-intensive industries & $\begin{array}{l}0.249 * * * \\
(0.033)\end{array}$ & $\begin{array}{l}0.074 \\
(0.058)\end{array}$ & $\begin{array}{l}0.057 \\
(0.056)\end{array}$ & $\begin{array}{l}0.059 \\
(0.059)\end{array}$ & $\begin{array}{l}0.033 \\
(0.057)\end{array}$ & $\begin{array}{l}-0.063 \\
(0.067)\end{array}$ \\
\hline Pre-WWII German heritage $($ yes $=1$ ) & No & Yes & Yes & Yes & Yes & Yes \\
\hline Pre-WWII controls & No & Yes & Yes & Yes & Yes & Yes \\
\hline Migration controls following WWII & No & No & Yes & Yes & Yes & Yes \\
\hline Pre-WWII German heritage $($ yes $=1) \times$ Pre-WWII controls & No & No & No & Yes & Yes & Yes \\
\hline Pre-WWII German heritage $($ yes $=1) \times$ migration resulting from WWII & No & No & No & No & Yes & Yes \\
\hline $\begin{array}{l}\text { Pre-WWII German heritage (yes }=1) \times \text { historical self-employment in } \\
\text { other than knowledge-intensive industries }\end{array}$ & No & No & No & No & No & $\begin{array}{l}0.319 * * * \\
(0.123)\end{array}$ \\
\hline Adjusted $\mathrm{R}^{2}$ & 0.143 & 0.401 & 0.466 & 0.418 & 0.517 & 0.526 \\
\hline
\end{tabular}

Notes: As in Table 1. Full table is presented in Table B.2 in the Appendix

resulting from WWII with the dummy indicating prewar 1945 German regions. In model VI, we add an interaction between the heritage dummy and the historical rate of self-employment in knowledge-intensive industries. The purpose of models IV-VI is to analyze differential effects of high-quality entrepreneurship and the control variables across the different types of regions. To economize on space, we do not show the results for control variables in the main section. For the full range of coefficient estimates, see Table B. $1^{10}$ in the Appendix.

The results of models I-VI reveal a significant positive effect of the historical rate of self-employment in knowledge-intensive industries on current start-up activity. In terms of level of impact, a one percent higher historical self-employment rate is associated with approximately a $0.17 \%$ higher start-up rate. We interpret the results to indicate that self-employment in knowledge-intensive manufacturing industries likely generates role model and peer effects that forge long-lasting positive attitudes in the populace towards entrepreneurship and start-up activity that continue

\footnotetext{
10 Table B.1 demonstrates a negative effect of the indigenous population proportion on current start-up activities, indicating that one percent higher proportion of indigenous population is associated with about $0.1 \%$ lower start-up rate in the reference area (pre-1918 Prussian territory). In the former German area this effect is close to zero (models V-VI) as adding the main negative effect and the German interaction effect reveals.
}

today. The interaction term of pre-war German heritage and the self-employment rate in knowledge-intensive manufacturing industries in model VI captures potential differences in the scope of impact for former German regions. The insignificance of the respective coefficient clearly indicates that the effect of historical knowledge-intensive entrepreneurship on current levels of new business formation is not different in in the former German regions where there were only relatively minor opportunities for an intergenerational transmission of entrepreneurship-facilitating values.

We also explore how historical levels of lower quality self-employment affect current start-up activity. Table 2 replicates the models of Table 1, but with historical self-employment in other non-agricultural private sector industries over total workforce. This rate is much larger on average, and mainly reflects the prevalence of historical (non-knowledge-intensive) self-employment in a region at large. However, it has no significant effect on current start-up activity in a region when controlling for pre-WWII structural characteristics and migration resulting from WWII (Table 2, models II-VI). There is a significant interaction effect between this type of historical selfemployment and the German heritage dummy, which in principle could be associated with a higher overall level of industrialization in these areas, but in fact is not, as further analysis shows.

We also run models using self-employment in nonknowledge-intensive manufacturing industries as a 
Table 3 Differences in start-up rates across Polish counties 2003-2019: The role of historical entrepreneurship in non-knowledgeintensive manufacturing industries

\begin{tabular}{|c|c|c|c|c|c|c|}
\hline & $(1)$ & $(2)$ & (3) & (4) & $(5)$ & (6) \\
\hline $\begin{array}{l}\text { Historical self-employment in non-knowledge-intensive manufactur- } \\
\text { ing industries }\end{array}$ & $\begin{array}{l}0.198 * * * \\
(0.036)\end{array}$ & $\begin{array}{l}-0.026 \\
(0.065)\end{array}$ & $\begin{array}{l}-0.033 \\
(0.062)\end{array}$ & $\begin{array}{l}-0.056 \\
(0.068)\end{array}$ & $\begin{array}{l}-0.074 \\
(0.064)\end{array}$ & $\begin{array}{l}-0.124 \\
(0.078)\end{array}$ \\
\hline Pre-WWII German heritage $($ yes $=1$ ) & No & Yes & Yes & Yes & Yes & Yes \\
\hline Pre-WWII controls & No & Yes & Yes & Yes & Yes & Yes \\
\hline Migration resulting from WWII & No & No & Yes & Yes & Yes & Yes \\
\hline Pre-WWII German heritage $($ yes $=1) \times$ Pre-WWII controls & No & No & No & Yes & Yes & Yes \\
\hline $\begin{array}{l}\text { Pre-WWII German heritage }(\text { yes }=1) \times \text { migration resulting from } \\
\text { WWII }\end{array}$ & No & No & No & No & Yes & Yes \\
\hline $\begin{array}{l}\text { Pre-WWII German heritage (yes }=1) \times \text { historical self-employment in } \\
\text { non-knowledge-intensive manufacturing industries }\end{array}$ & No & No & No & No & No & $\begin{array}{l}0.159 \\
(0.139)\end{array}$ \\
\hline Adjusted $\mathrm{R}^{2}$ & 0.082 & 0.398 & 0.465 & 0.417 & 0.519 & 0.519 \\
\hline
\end{tabular}

Notes: As in Table 1. Full table is presented in Table B.3 in the Appendix

variable, to rule out that our main results are reflecting a manufacturing rather than a knowledge-intensity pattern. The results show that there is no significant effect for this self-employment rate (Table 3) when controlling for regional determinants of start-up activity.

To further test the strength of our results, we analyze the data for the general level of historical entrepreneurship on current start-up activity (see Table B.4 in the Appendix). There is no significant relationship. Hence, we can confirm that there is no persistent effect of the general historical level of entrepreneurship. We also investigate the effect of knowledgeintensive entrepreneurship on start-up rates in the period of 2012 to 2019 , to rule out the possibility that our main analysis was influenced by the Global Financial Crisis of 2008, and the admission of Poland to the European Union in 2004 (Table B.5). The results confirm that there is also a robust positive significant effect for this second period.

\section{Discussion and conclusions}

\subsection{Main findings}

We analyze how different types of historical selfemployment affect current entrepreneurship in diverse regional contexts of Poland that saw different degrees of disruptive shocks over the course of the last 100 years. A main finding is that there is a highly significant relationship between historical self-employment in knowledge-intensive industries and current levels of general new business formation. Historical self-employment in other industries or historical self-employment in general plays no meaningful role in the explanation of current entrepreneurship levels. This result is rather remarkable because the share of historical self-employment in knowledge-intensive industries made only a rather small fraction of overall self-employment. Assuming that self-employment in knowledge-intensive industries represents entrepreneurship of a relatively high quality (see Section 2.2), our finding clearly indicates that it is more the quality than the quantity of entrepreneurship that creates historical roots. The result also point to an important role of the regional knowledge stock for the quality of regional entrepreneurship. The non-relatedness of historical self-employment in other industries with current levels of entrepreneurship is in stark contrast to previous research (e.g., Andersson \& Koster, 2011; Fotopoulos \& Storey, 2017; Fritsch \& Wyrwich, 2014) that found pronounced effects of historical self-employment outside of knowledgeintensive industries. Our main conclusion is that the historical regional knowledge stock as reflected by knowledge-intensive entrepreneurship can be an important root of contemporary entrepreneurship despite disruptive historical shocks. 
A further important result of our analysis is that persistence of the population does not make any significant difference with respect to the strength of the impact of a historical tradition of knowledge-intensive entrepreneurship on current start-up activity. It is particularly remarkable that we do not find significant differences in the effect of knowledge-intensive entrepreneurship between former German areas where the original German population was almost completely expelled after World War II, and other parts of Poland. Our attempt to explain these results is based on the presumption that historical knowledge-intensive entrepreneurship was relatively successful with a pronounced positive impact on regional development. A collective memory of such positive examples of entrepreneurship may then have stimulated new business formation among the new population.

\subsection{Policy implications}

Our finding that the historical level of knowledgeintensive self-employment is positively related to current start-up activity clearly points to the role of education and knowledge for entrepreneurship and development. The significant long-lasting impact of firms in the knowledge-intensive part of the economy suggests that policy should attempt to especially stimulate the emergence of such type of firms in a region. Although the number of such firms may be small, their effect can be rather important and persistent. This may particularly hold for highly innovative startups that may require specific types of support. Stimulating such firms includes measures to create and support a regional knowledge base that constitutes a necessary precondition for knowledge-intensive entrepreneurship.

A further policy recommendation is to support the dissemination of entrepreneurial success stories that provide roadmaps on how to become effective entrepreneurs, and potentially create a place-based collective memory. A collective memory of successful entrepreneurship could also be the nucleus of the (re-)emergence of a local entrepreneurial culture and a business climate that is conducive to new firms. Examples of historically successful role models could be a starting point for stimulating current entrepreneurship. Once active, these current entrepreneurs can be regarded as role models for future entrepreneurs via direct demonstration and peer effects. This may create a circle of new firm formation, demonstration and peer effects, and increase social acceptance of entrepreneurs. These factors may reinforce each other and encourage the self-perpetuation of entrepreneurship over time (Fritsch \& Wyrwich, 2019).

\subsection{Limitations and avenues for further research}

An important limitation of our study is the availability of data. In particular, we do not have any information about the economic success of historical firms back in the 1920s. Moreover, we have no measures that could be used to test our conjecture about the role of a collective memory such as values and attitudes of the today's regional population (for such an analysis see Fritsch et al., 2019a). We also lack information on the development of regional differences of self-employment during the communist period. This would allow us to investigate if regions with relatively high levels of entrepreneurship in the 1920 were also more entrepreneurial in the socialist system as was found in the case of East Germany (Fritsch \& Wyrwich, 2014). Generally, more research is warranted to explore historical roots of regional entrepreneurship and to understand the channels by which historical levels and types of entrepreneurship can shape new business formation today. In particular it would be interesting to know more about the effect of different kinds of economic, social, political, and institutional context have on regional entrepreneurship and development.

A key task of future research is to make longer time-series of more and better data available. This includes information on different types of entrepreneurship, about government policies towards entrepreneurship and the supporting infrastructure, as well as information about the historical and current social values and attitudes of the regional population. A particular issue is information about regional knowledge and innovation activity in earlier periods that allows to account for their relationship with entrepreneurship. An important direction of data mining would be to gather information about earlier historical eras that allow for an investigation of regional development trajectories over longer periods of time. Such data may particularly help to better understand the determinants of historical entrepreneurial activity. Why did some places become more entrepreneurial in history than others? Why did self-employment and new business formation decline in regions that once 
experienced an entrepreneurial boom? How to avoid a severe economic downturn in "old-industrialized" regions and how can such regions be re-vitalized? Such investigations of historical contexts for entrepreneurship could probably benefit from collaboration between economists, historians, political scientists, and researchers from other disciplines.

An important question still unanswered is why self-employment in knowledge-intensive industries plays such an important role. What makes knowledge-intensive entrepreneurship special? What are the sources of the stark regional differences in historical industry structures and levels of self-employment?

While the transfer of an entrepreneurial spirit from parents to their offspring has been well investigated in the literature (e.g., Chlosta et al., 2012; Dohmen et al., 2012; Laspita et al., 2012; Lindquist et al., 2015), we still know very little about these patterns when the original population was more or less completely exchanged, as was the case in those Polish regions that belonged to Germany until WWII. How is a place-based collective memory able to survive severe disruptive shocks to social, political, and economic conditions? Is the existing infrastructure a source of persistence? Perhaps, spatial mobility plays a role: Are people with an entrepreneurial mindset particularly attracted to regions that are characterized by high levels of entrepreneurship?

It would be interesting to explore the role of historical knowledge-intensive high-quality entrepreneurship in other contexts. A further point that deserves attention is the design of appropriate political strategies. How can policy support the emergence and development of high-quality entrepreneurship? Will this development encourage the emergence of a place-based collective memory of successful entrepreneurship? Do regions with a strong tradition of high-quality entrepreneurship respond differently to certain policy measures when compared to regions without such a tradition? We are still seeking answers to these and other questions.

Supplementary Information The online version contains supplementary material available at https://doi.org/10.1007/ s11187-021-00535-z.

Acknowledgements We are indebted to Marcus Dejardin, Sierdjan Koster, Tomasz Mickiewicz, Michael Stuetzer and two anonymous referees for helpful comments on an earlier version of this paper.
Data availability (data transparency) Data is available upon request

Code availability (software application or custom code) NA

\section{Declarations}

Conflicts of interest The authors declare no competing interests.

Open Access This article is licensed under a Creative Commons Attribution 4.0 International License, which permits use, sharing, adaptation, distribution and reproduction in any medium or format, as long as you give appropriate credit to the original author(s) and the source, provide a link to the Creative Commons licence, and indicate if changes were made. The images or other third party material in this article are included in the article's Creative Commons licence, unless indicated otherwise in a credit line to the material. If material is not included in the article's Creative Commons licence and your intended use is not permitted by statutory regulation or exceeds the permitted use, you will need to obtain permission directly from the copyright holder. To view a copy of this licence, visit http://creativecommons.org/licenses/by/4.0/.

\section{References}

Acs, Z. J., Braunerhjelm, P., Audretsch, D. B., \& Carlsson, B. (2009). The knowledge spillover theory of entrepreneurship. Small Business Economics, 32(1), 15-30. https://doi. org/10.1007/s11187-008-9157-3

Andersson, M., \& Koster, S. (2011). Sources of persistence in regional start-up rates-evidence from Sweden. Journal of Economic Geography, 11(1), 179-201. https://doi.org/10. 1093/jeg/lbp069

Aslund, A. (1985). Private enterprise in Eastern Europe: The non-agricultural private sector in Poland and the GDR, 1945-83. Palgrave Macmillan UK.

Audretsch, D. B., \& Fritsch, M. (1994). On the measurement of entry rates. Empirica, 21(1), 105-113. https://doi.org/10. 1007/BF01383974

Becker, S. O., Grosfeld, I., Grosjean, P., Voigtländer, N., \& Zhuravskaya, E. (2020). Forced migration and human capital: Evidence from post-WWII population transfers. American Economic Review, 110, 1430-1363. https://doi. org/10.1257/aer.20181518

Bleakley, H., \& Lin, J. (2012). Portage and path dependence. Quarterly Journal of Economics, 127, 587-644.

Chlosta, S., Patzelt, H., Klein, S. B., \& Dormann, C. (2012). Parental role models and the decision to be-come selfemployed: The moderating effect of personality. Small Business Economics, 38, 121-138. https://doi.org/10. 1007/s11187-010-9270-y

Curp, D. (2006). A clean sweep?: The politics of ethnic ceansing in Western Poland, 1945-1960. Boydell \& Brewer.

Dalgaard, C.-J., Kaarsen N., Olsson O., \& Selaya P. (2018). Roman roads to prosperity: Persistence and non-persistence of public goods provision, mimeo. 
David, R. J., Sine, W. D., \& Serra, C. K., et al. (2017). Institutional theory and entrepreneurship: Taking stock and moving forward. In R. Greenwood, C. Oliver, \& T. B. Lawrence (Eds.), SAGE Handbook of Organizational Institutionalism (2nd ed., pp. 671-688). SAGE Publications.

Davies, N., \& Moorhouse, R. (2011). Microcosm: A portrait of a Central European city. Vintage Digital.

Davis, D. R., \& Weinstein, D. E. (2002). Bones, bombs, and break points: The geography of economic activity. American Economic Review, 92(5), 1269-1289. https://doi.org/ $10.1257 / 000282802762024502$

Dohmen, T., Falk, A., Huffman, D., \& Sunde, U. (2012). The intergenerational transmission of risk and trust attitudes. Review of Economic Studies, 79, 645-677. https://doi.org/ $10.1093 / \mathrm{restud} / \mathrm{rdr} 027$

Fotopoulos, G. (2014). On the spatial stickiness of UK new firm formation rates. Journal of Economic Geography, 14(3), 651-679. https://doi.org/10.1093/jeg/lbt011

Fotopoulos, G., \& Storey, D. J. (2017). Persistence and change in interregional differences in entrepreneurship: England and Wales, 1921-2011. Environment and Planning A, 49(3), 670-702. https://doi.org/10.1177/0308518x16 674336

Fritsch, M., Bublitz, E., Sorgner, A., \& Wyrwich, M. (2014). How much of a socialist legacy? The re-emergence of entrepreneurship in the East German transformation to a market economy. Small Business Economics, 43(2), 427446. https://doi.org/10.1007/s11187-014-9544-X

Fritsch, M., \& Kublina, S. (2019). Persistence and change of regional new business formation in the national league table. Journal of Evolutionary Economics, 29, 891-917. https://doi.org/10.1007/s00191-019-00610-5

Fritsch, M., Obschonka, M., \& Wyrwich, M. (2019a). Historical roots of entrepreneurial culture and innovation activity-an analysis for German regions. Regional Studies. https://doi.org/10.1080/00343404.2019.1580357

Fritsch, M., Sorgner, A., Wyrwich, M., \& Zazdravnykh, E. (2019b). Historical shocks and persistence of economic activity: Evidence on self-employment from a unique natural experiment. Regional Studies, 53, 790-802. https:// doi.org/10.1080/00343404.2018.1492112

Fritsch, M., \& Wyrwich, M. (2014). The long persistence of regional levels of entrepreneurship: Germany, 1925-2005. Regional Studies, 48(6), 955-973. https://doi.org/10.1080/ 00343404.2013 .816414

Fritsch, M., \& Wyrwich, M. (2018). Regional knowledge, entrepreneurial culture, and innovative start-ups over time and space-an empirical investigation. Small Business Economics, 51, 337-353. https://doi.org/10.1007/ s11187-018-0016-6

Fritsch, M., \& Wyrwich, M. (2019). Regional trajectories of entrepreneurship, knowledge, and growth-The role of history and culture. Springer. https://doi.org/10.1007/ 978-3-319-97782-9

Geiss, I. (2013). The question of German unification: 18061996. Routledge.

Gerber, T.P. (2004). Three forms of emergent self-employment in post-Soviet Russia: Entry and exit patterns by gender. In R. Arum, \& W. Müller (eds.), The Reemergence of SelfEmployment: A Comparative Study of Self-Employment
Dynamics and Social Inequality. Princeston University Press.

Gieryn, T. F. (2000). A space for place in sociology. Annual Review of Socilogy, 26, 463-496. https://doi.org/10.1146/ annurev.soc.26.1.463

Glaeser, E. L., Kerr, S. P., \& Kerr, W. R. (2015). Entrepreneurship and urban growth: An empirical assessment with historical mines. Review of Economics and Statistics, 97, 498-520. https://doi.org/10.1162/REST_a_00456

GUS: Główny Urząd Statystyczny Rzeczypospolitej Polskiej (1927), Pierwszy Powszechny Spis Rzeczypospolitej Polskiej z dnia 30 września 1921 roku. Mieszkania. Ludność. Stosunki zawodowe [The First General Census of the Republic of Poland of 30 September 1921. Housing. Population. Professional relations], Warsaw, Vols. XIV-XXX.

Kokot, J. (1959). The logic of the Oder-Neisse frontier. Wydawn. Zachodnie.

Koryś, P. (2018). Poland from partitions to EU accession: A modern economic history, 1772-2004. Palgrave Macmillan.

Kosiński, L. (1963). Demographic processes in the recovered territories from 1945 to 1960. Institute of Geography Polish Academy of Sciences.

Kouli, Y. (2014). Wissen und nach-industrielle Produktion. Das Beispiel der gescheiterten Rekonstruktion Niederschlesiens 1936-1945. Franz Steiner Verlag.

Laspita, S., Breugst, N., Heblich, S., \& Patzelt, P. (2012). Intergenerational transmission of entrepreneurial intentions. Journal of Business Venturing, 27, 414-435. https://doi.org/10.1016/j.jbusvent.2011.11.006

Lindquist, M., Sol, J., \& van Praag, M. (2015). Why do entrepreneurial parents have entrepreneurial children? Journal of Labour Economics, 33, 269-296. https://doi. org/10.1086/678493

Macieja, J. (2001). Private and public sector: New and old patterns of entrepreneurship. In R., Rapacki, \& G. G., Blazyca (eds.), Poland into the New Millennium. Edward Elgar: Cheltenham \& Northampton, MA.

Marquis, C., \& Battilana, J. (2009). Acting globally but thinking locally? The Enduring Influence of Local Communities on Organizations. Research in Organizational Behavior, 29, 283-302. https://doi.org/10.1016/j.riob.2009.06. 001

North, D. C. (1994). Economic-performance through time. American Economic Review, 84(3), 359-368.

Olick, J. K., Vinitzky-Seroussi, V., \& Levy, D. (2011). Introduction. In J. K. Olick, V. Vinitzky-Seroussi, \& D. Levy (Eds.), The Collective Memory Reader (pp. 3-62). Oxford University Press.

Pierenkemper, T. (1979). Entrepreneurs in heavy industry: Upper Silesia and the Westphalian Ruhr Region, 1852 to 1913. Business History Review, 53, 65-78.

Rutkowski, J.J. (1998). Welfare and the labor market in Poland: Social policy during economic transition, World Bank Technical Paper No. 417, Social Challenges of Transition Series. World Bank: Washington DC.

Statistik des Deutschen Reichs. (1927, 1929). Vols. 401-405; 415.

Sawicki, J. S., \& Sawicka-Brockie, T. A. (1982). Embattled Poland: An historical reflection: Reflections on an ethnic journey. Victoria University Press. 
Stuetzer, M., Obschonka, M., Audretsch, D. B., Wyrwich, M., Rentfrow, P. J., Coombes, M., Shaw-Taylor, L., \& Satchell, M. (2016). Industry structure, entrepreneurship, and culture: An empirical analysis using historical coalfields. European Economic Review, 86, 52-72. https://doi.org/ 10.1016/j.euroecorev.2015.08.012

Tipton, F. B. (1974). Farm labor and power politics - Germany, 1850-1914. Journal of Economic History, 34(4), 951979. https://doi.org/10.1017/s0022050700089373
Williamson, O. E. (2000). The new institutional economics: Taking stock, looking ahead. Journal of Economic Literature, 38(3), 595-613.

Zukin, S. (2011). Reconstructing the authenticity of place. Theory and Society, 40, 161-165. https://doi.org/10.1007/ s11186-010-9133-1

Publisher's note Springer Nature remains neutral with regard to jurisdictional claims in published maps and institutional affiliations. 